\title{
Develop mechanisms to attract budgetary and extra-budgetary fund to improve the functioning of public education institutions
}

\author{
I. SIRADJEV 1 \\ Ministry of Public Education
}

\begin{tabular}{l} 
ARTICLE INFO \\
\hline Article history: \\
Received October 2021 \\
Received in revised form \\
15 October 2021 \\
Accepted 15 November 2021 \\
Available online \\
25 December 2021 \\
\hline
\end{tabular}

\section{Keywords:}

mechanism,

make your school more

sustainable,

turn off lights in empty

rooms,

automation of business

processes.

\begin{abstract}
To date, improving the level of activity of state educational institutions is a priority task. And also, their increase to the level corresponding to modern educational standards. This is possible, largely depending on the attraction and effective use of various financial and administrative resources. The main source of education is the State budget. However, the state budget is very limited, and there are many areas and sectors (problems) that require budget control. Thus, the state allocates financial resources, according to the adopted budget. At the same time, it is necessary to prevent the stagnation of the educational process and its deterioration due to lack of funds. There are two possible solutions to the problem: the first is the effective and targeted use of allocated budget funds, and the second is to increase the level of interest in attracting extra-budgetary funds.
\end{abstract}

2181-1415/C 2021 in Science LLC.

DOI: https://doi.org/10.47689/2181-1415-vol2-iss11/S-pp21-25

This is an open access article under the Attribution 4.0 International (CC BY 4.0) license (https://creativecommons.org/licenses/by/4.0/deed.ru)

\section{Xalq ta'limi muassasalari faoliyatini tashkillash uchun byudjet va byudjetdan tashqari jamg'arma mablag'larini jalb etish mexanizmlarini ishlab chiqish}

\author{
Калит сўзлар: \\ mexanizm, \\ maktabingizni yanada \\ barqaror qilish, \\ bo'sh xonalarda chiroqlarni \\ o'chirish, \\ biznes jarayonlarini \\ avtomatlashtirish
}

\begin{abstract}
АННОТАЦИЯ
Bugungi kunda xalq ta'limi muassasalari faoliyatini takomillashtirish, ularni zamonaviy ta'lim standartlariga javob beradigan darajaga ko'tarish ko'p jihatdan turli mablag'larni jalb etish va ulardan samarali foydalanishga bog'liq. Ta'limning asosiy manbai davlat byudjeti hisoblanadi. Biroq davlat byudjeti juda cheklangan va byudjetni talab qiladigan ko'plab sohalar va tarmoqlar (muammolar) mavjud. Shunday qilib, davlat ta'limga
\end{abstract}

\footnotetext{
${ }^{1}$ Head of Financial Analysis and Planning Department, Ministry of Public Education. Tashkent, Uzbekistan.
} 
xohlagancha mablag' ajrata olmaydi. Shu bilan birga, ta'limtarbiya jarayonining to'xtab qolishiga, mablag' yetishmasligi tufayli yomonlashishiga yo'l qo'ymaslik zarur. Eng muhim ikkita yechim bor: birinchisi, ajratilgan byudjet mablag'laridan samarali va maqsadli foydalanish, ikkinchisi, budjetdan tashqari mablag'larni jalb qilishni yaxshilash.

\section{Разработка механизмов привлечения бюджетных и внебюджетных средств для улучшения функционирования государственных образовательных учреждений}

Ключевые слова:

механизм,

повышение устойчивости

школы,

выключение света в пустых помещениях, автоматизация бизнеспроцессов.

\begin{abstract}
АННОТАЦИЯ
На сегодняшний день, улучшение уровня деятельности государственных образовательных учреждений, приоритетная задача. А также, их повышение до уровня, соответствующего современным образовательным стандартам. Это возможно, во многом зависит от привлечения и эффективного использования различных финансовых и административных средств. Основным источником образования является государственный бюджет. Однако, государственный бюджет очень ограничен, и есть много областей и секторов (проблем), которые, требуют контроля бюджета. Таким образом, государство выделяет финансовые средства, согласно принятому бюджету. В то же время, необходимо не допускать стагнации учебного процесса и его ухудшения изза нехватки средств. Возможно два решения проблемы: первое - это эффективное и целевое использование выделенных бюджетных средств, а второе - повышение уровня заинтересованности в привлечении внебюджетных средств.
\end{abstract}

Funding for education is usually insufficient. We can see that a lot of research is being done not only in Uzbekistan, but all over the world, even in the United States, on the lack of funding for schools. A study by The Education Trust found that relatively poor areas in the United States are funded at around $\$ 1,000$ per student, while relatively rich areas are funded at $\$ 1,800$. This means that almost twice as much funding leads to systemic inequality along with injustice in the fight for student success. In another survey in the United States, 81 percent of teachers reported their schools. At the same time, it is reported that the cost of running the school is increasing, which helps students to succeed.

Is researcher Lenny Kennedy talking about budget cuts for educational institutions? To the question of how to effectively manage the allocated budget funds, he asked 6 ways.

The example of researcher Kennedy's US schools can be applied to many Uzbek schools. There are 6 ways to effectively manage funds suggested by the researcher:

1) Make your school more sustainable

As school leaders strive to create a more sustainable environment, this will help reduce unnecessary costs. For example, many schools still use old papers for accounting, 
payroll, and enrollment. As schools switch to online alternatives, the cost of printing and using paper can be reduced. This saves money and helps the environment. Schools can also take steps to reduce electricity, water and heating costs. Schools in the United States consume more than $\$ 6$ billion a year in energy, but research shows that if schools use energy wisely, costs could be reduced by 25 percent. The Seattle school saved $\$ 20,000$ a year by installing automated (self-extinguishing) lights.

Here are some ways to reduce your school's energy consumption:

- Use sunlight (natural light) to reduce energy costs

- Turn off lights in empty rooms

- Use moving (automated) lights

- Turn off computers and printers at night and on weekends

- Prevent or ensure efficient operation of the heating system through regular cultivation planning.

2) Search for economical (or free) options (search for cost-effective (or costeffective) options)

With a little effort, you can find options that provide more choice instead of money and help reduce school costs. For example, when buying equipment and machinery, you can look for cheaper or cheaper options.

3) Be careful when renewing contracts (be aware of contract renewals)

To reduce costs, school leaders need to know where their money is going. When renewing a contract, for services such as cleaning, insurance, or electricity, consider them before extending it for another year. While this may take a little extra time, shopping to make sure you get the best deal can save you hundreds (if not thousands) of dollars at your school.

4) Use the school website to raise money

Did you know that your school has the potential to generate its own income? Local organizations and businesses may need space for events such as classes, business meetings, or training. Even your parking lot (parking lot) can be used to make money:

if it is located in a strategic area, you can rent it as a paid parking space for local events. Every school can be creative about fundraising methods. Start by analyzing the vacancies in your school and the times when these gaps are not used. Then contact local organizations to find out who might need the space, or let the community know if the space can be rented.

5) Automation of business processes

All repetitive processes, such as payroll, billing, or maintenance requirements, can be automated. There are many tools available to automate business processes, and most of them are relatively economical. The money you spend on automating these business processes will be returned to you by increasing productivity. This means you can save valuable time that can be applied in other ways, which can ultimately save money on labor.

6) Invest in teachers

No matter how bad your budget is, never give up investing in your teachers. They are the backbone of your school, and without their constant support and hard work, your students will never succeed. An article by the Thomas B. Fordham Institute states that schools strive for a smaller and more efficient workforce that will be rewarded for taking on more responsibility in return for a good salary. As a result, this can lead to better use of the budget and a compensation system that increases the satisfaction of school staff. 
Research shows that the goal of any school leader is to ensure that students succeed and grow up to be talented and intelligent. Although the issue of school funding will not be resolved in the near future, this does not mean that school leaders are weak. Yes, of course, many schools in the world today have a limited budget. However, as a school principal, you can strive to make better use of your existing budget. By simplifying the process, finding cost-effective options, and reducing school renovation costs, you can spend more money on teachers. It may take some time to develop your cost reduction strategy, but it can be a cost-effective school that benefits students more without increasing your budget.

Because public schools are not set up for more financial gain than private schools, public school principals sometimes drop out of school and neglect business relationships. However, the financial and economic relationship of the school principal is very complex. For example: financial incentives for supervisors, timely delivery control, etc. are the responsibilities of the school administration, and only the school principal is responsible for making decisions and managing the process. Therefore, school principals need to have knowledge and skills in certain areas, such as the economics of education, budgeting and resource use, says researcher Dembowski.

Today, the number of private schools is growing, and in many countries, schools are funded from the state budget by enrolling students. That is, the more students you can attract, the more money you will get from the budget. For example, in some cities of Kazakhstan (Almaty, Aktobe, etc.) this method is used. The purpose of this method is, simply put, per capita funding, i.e. budget money goes through the student. Of course, this method has its advantages and disadvantages. Although this method is not used in Uzbekistan, it is well known that parents want their children to go to the best school in the district or city. As a result, the number of students and classes in some schools will increase (which is also negative), which will lead to more budget transfers. In addition, the emergence of private schools, charter schools, and voucher programs is changing the dynamics of school coverage. In this case, public schools are competing and even finding it difficult to attract budget funds. Therefore, it is necessary to have a good marketing policy in order to attract not only students but also qualified teachers in schools today. As NASSP researchers point out, as in business, schools also need to decide which aspects (e.g., music, sports, and school buildings) may be the best offer for the population. Also, each school must create its own system of values (concepts). It involves not only the community, students and teachers, but also a wide range of material resources (budget and extrabudgetary funds).

As Mark Perna points out, "Every smart principal and teacher who cannot continue or expand the school enrollment process without marketing and wants to survive the onslaught of educational opportunities available today will actively promote their program. ib can".

\section{REFERENCES:}

1. Lauren Ramakrishna, 4 Ways to Help Underserved School Kids // https://www.thathelps.com/4-ways-to-help-underserved-school kids/utm_source= social\&utm_medium=facebook\&utm_campaign=education (Маълумотга эришилган тарих: 14.06 .2021

2. Laney Kennedy, 6 Actionable Ways to Use School Funding More Efficiently. 
3. Laney Kennedy, 6 Actionable Ways to Use School Funding More Efficiently, June 14, 2019 // https://www.prodigygame.com/main-en/blog/school-funding.

4. NASSP, Changed Role - Preparing for The Future, Changing Role of the Middle Level and High School Leader: Learning from the Past - Preparing for the Future, National Association of Secondary School Principals, 2007. - P. 10.

5. Aryn A.A., Issakhova P.B., Education Financing in the Republic of Kazakhstan: Problems of Ensuring Efficiency and Effectiveness. European Research Studies Journal, Volume XXI, Issue 2, 2018, - PP. 83-94. 